\title{
PENGALIHAN BEA PEROLEHAN HAK ATAS TANAH DAN BANGUNAN (BPHTB) DARI PAJAK PUSAT MENJADI PAJAK DAERAH SEBAGAI UPAYA PENINGKATAN PENDAPATAN ASLI DAERAH (PAD)
}

\author{
Rini Irianti Sundary \\ Dosen Fakultas Hukum Universitas Islam Bandung \\ e-mail: rinisundary@gmail.com
}

\begin{abstract}
Abstrak-Pengaturan kewenangan perpajakan dan retribusi yang ada saat ini kurang mendukung pelaksanaan otonomi Daerah. Pemberian kewenangan yang semakin besar kepada Daerah dalam penyelenggaraan pemerintahan dan pelayanan kepada masyarakat seharusnya diikuti dengan pemberian kewenangan yang besar pula dalam perpajakan dan retribusi. Berdasarkan Pasal 180 angka (6) Undang-Undang Nomor 28 Tahun 2009 tentang Pajak Daerah dan Restribusi, pemerintah daerah dapat memungut BPHTB dengan syarat menerbitkan peraturan daerah yang berkaitan mengenai itu. Permasalahan yang diangkat dalam tulisan ini yaitu pengalihan BPHTB dari pajak pusat menjadi pajak daerah dalam hubungannya dengan prinsip-prinsip umum perpajakan daerah. Dan sejauhmana pemungutan BPHTB sebagai pajak daerah dalam meningkatkan Pendapatan Asli Daerah (PAD). Hasil dari penelitian ini membuktikan bahwa penetapan BPHTB sebagai pajak daerah akan meningkatkan pendapatan yang bersumber dari daerah itu sendiri (Pendapatan Asli Daerah) Hal ini berbeda dengan penerimaan BPHTB sebagai pajak pusat, meskipun pendapatan BPHTB kemudian diserahkan kepada daerah, penerimaan ini tidak dimasukkan ke dalam kelompok pendapatan asli daerah, melainkan sebagai dana perimbangan (dana bagi hasil). BHPTB sebagai pajak daerah juga dapat meningkatkan akuntabilitas daerah (local accountability). Dengan menetapkan BPHTB sebagai pajak daerah, maka kebijakan BPHTB ditetapkan oleh daerah dan disesuaikan dengan kondisi, dan tujuan pembangunan daerah.
\end{abstract}

\section{Kata Kunci: Pajak Daerah, BPHTB, Pendapatan Asli Daerah.}

Abstract-The current regulation of tax and levy authority does not support the implementation of regional autonomy. Providing greater authority to the Regions in the administration and service to the public should be followed by the granting of great authority in taxation and retribution too. Pursuant to Article 180 point (6) of Law Number 28 The year 2009 regarding Regional Tax and Restribution, the local government may collect BPHTB on condition of issuing the related local regulation concerning it. The issue raised in this paper is the transfer of BPHTB from the central tax to local taxes in conjunction with the general principles of local taxation. And how far the collection of BPHTB as a local tax in increasing the Local Revenue (PAD). The results of this study prove that the determination of BPHTB as a local tax will increase the revenues sourced from the region itself (Original Revenue) This is different from the acceptance of BPHTB as a central tax, although the BPHTB income will then submitted to the region, this acceptance is not included in the local revenue group, but instead as a balanced fund (profit sharing). BHPTB as a local tax can also increase local 
Rini Irianti Sundary, Pengalihan Bea Perolehan Hak Atas Tanah Dan Bangunan (Bphtb) Dari...

accountability. By establishing BPHTB as a local tax, BPHTB's policy is defined by the regions and adapted to the conditions and objectives of regional development.

Keywords: Local Taxes, BPHTB, Local Revenue.

\section{A. PENDAHULUAN}

Bea Perolehan Hak Atas Tanah

Dan Bangunan atau seterusnya disebut BPHTB merupakan pajak yang harus dibayar masyarakat dari diperolehnya hak atas tanah dan bangunan yang meliputi hak milik, hak guna usaha, hak guna bangunan, hak pakai, hak milik atas satuan rumah susun, dan hak pengelolaan. Bea ini dipungut ketika pembelian rumah ataupun tanah yang seringkali pengurusannya dilakukan oleh pengembang dan biayanya dibebankan pada biaya penjualan.

Sejak 1 Januari 2011, pemerintah pusat tidak lagi menarik bea tersebut. Berdasarkan Pasal 180 angka (6) Undang-Undang Nomor 28 Tahun 2009 tentang Pajak Daerah dan Restribusi, pemerintah daerah dapat memungut BPHTB dengan syarat menerbitkan peraturan daerah yang berkaitan mengenai itu. Pengalihan kewenangan pemungutan BPHTB dari pusat ke daerah didasarkan pada pertimbangan efisiensi dan dalam upaya menata kembali sistem perpajakan nasional yang dikaitkan dengan pelaksanaan otonomi daerah dan desentralisasi fiskal, maka dengan Undang-Undang Nomor 28 Tahun 2009, BPHTB dialihkan dari pajak pusat menjadi pajak kabupaten/kota. Undang-Undang Nomor 28 Tahun 2009 ditetapkan pada tanggal 15 September 2009 dan berlaku secara efektif pada tanggal 1 Januari 2010. Khusus untuk BPHTB, mulai dapat dipungut oleh daerah pada tanggal 1 Januari 2011.

Dasar pemikiran perubahan kebijakan ini juga dapat dilihat dalam landasan umum Undang-Undang Nomor 28 Tahun 2009, yang menyebutkan antara lain bahwa Pengaturan kewenangan perpajakan dan retribusi yang ada saat ini kurang mendukung pelaksanaan otonomi Daerah. Pemberian kewenangan yang semakin besar kepada Daerah dalam penyelenggaraan pemerintahan dan pelayanan kepada masyarakat seharusnya diikuti dengan pemberian kewenangan yang besar pula dalam perpajakan dan retribusi. Kebijakan 
Rini Irianti Sundary, Pengalihan Bea Perolehan Hak Atas Tanah Dan Bangunan (Bphtb) Dari...

ini juga ditujukan untuk terlihat bahwa potensi BPHTB belum meningkatkan akuntabilitas keuangan daerah, karena dengan dialihkannya kewajiban pajak dan retribusi kepada pemerintah daerah masing-masing, maka masyarakat daerah dapat secara langsung ikut mengkontrol, apakah pajak yang mereka bayarkan itu betul-betul dipergunakan untuk kepentingan masyarakat daerahnya.

Pengalihan Bea Perolehan Hak atas Tanah dan Bangunan (BPHTB) dari pajak pusat menjadi pajak daerah merupakan langkah strategis dalam pelaksanaan desentralisasi fiskal di Indonesia. Disamping memiliki justifikasi teknis, pengalihan ВРНТВ menjadi pajak daerah akan dapat meningkatkan pendapatan asli daerah (PAD) sebagai salah satu sarana untuk meningkatkan kualitas belanja daerah (local spending quality). Peningkatan kualitas belanja daerah akan memperbaiki kualitas pelayanan publik yang merupakan tujuan dari kebijakan otonomi daerah dalam rangka meningkatkan kesejahteraan masyarakat.

Berdasarkan data dari Departemen Keuangan, realisasi penerimaan BPHTB tahun 2009, merata. Sekitar 98,5\% dari realisasi penerimaan BPHTB Tahun 2009 dipungut di 235 kabupaten/kota (48\% dari jumlah kabupaten/kota).

Sisanya, sebanyak $1,5 \%$ BPHTB dipungut di 257 kabupaten/kota $\quad(52 \%$ dari jumlah kabupaten/kota). Kondisi yang demikian berpotensi menghambat implementasi pengalihan BPHTB. Daerah yang memiliki potensi BPHTB tinggi cenderung aktif mempersiapkan pemungutan BPHTB, sebaliknya daerah yang memiliki potensi BPHTB rendah cenderung bertindak pasif. Namun, sampai dengan 31 Juli 2011, daerah yang telah mulai memungut BPHTB telah mencapai 409 Kabupaten/Kota yang meliputi sekitar 99,5\% dari total potensi penerimaan BPHTB (Kementerian Keuangan, 2011).

Dengan menetapkan BPHTB sebagai pajak daerah, maka kebijakan BPHTB ditetapkan oleh daerah dan diseuaikan dengan kondisi, dan tujuan pembangunan daerah. Di samping itu untuk implementasi pungutan BPHTB, pemerintah daerah harus membuat Peraturan Daearah. Dan 
Rini Irianti Sundary, Pengalihan Bea Perolehan Hak Atas Tanah Dan Bangunan (Bphtb) Dari...

proses berikutnya yang harus bahan hukum primer berupa dilakukan adalah pemberdayaan penelahaan asas-asas dan kaidah daerah untuk segera mempersiapkan hukum yang mengatur tentang pemungutan BPHTB sesuai jadwal pemungutan pajak dan retribusi waktu yang ditetapkan dalam undang- daerah, serta pengaturan tentang undang. Seluruh aspek pemungutan BPHTB menjadi tanggung jawab BPHTB dalam upaya peningakatan PAD.

pemerintah daerah (Kabupaten/Kota) mulai dari perumusan kebijakan, pelaksanaan pemungutan dan pemanfaatan pendapatan yang berasal dari BPHTB, karenanya perlu juga dibentuk Peraturan Pelaksana dalam bentuk Peraturan Bupati/Peraturan Walikota yang memenuhi landasan yuridis, filosofi dan sosiologis, demi kemajuan pembangunan dan kesejahteraan masyarakat.

Berdasarkan uraian di atas, maka dalam tulisan ini akan dikaji bagaimanakan pengalihan BPHTB dari pajak pusat menjadi pajak daerah dalam hubungannya dengan prinsipprinsip umum perpajakan daerah? Dan sejauhmana pemungutan BPHTB sebagai pajak daerah dalam meningkatkan Pendapatan Asli Daerah (PAD)?

Dalam penulisan ini digunakan metode yuridis normatif, dengan lebih mengutamakan mencari dan meneliti

\section{B. HASIL DAN PEMBAHASAN}

\section{Pajak Daerah}

Pajak adalah iuran wajib yang dipungut oleh pemerintah dari masyarakat (wajib pajak) untuk menutupi pengeluaran rutin negara dan biaya pembangunan tanpa balas jasa yang dapat ditunjuk secara langsung. Pengetian pajak menurut beberapa ahli:

a. Adriani, pajak adalah iuran masyarakat kepada negara yang dapat dipaksakan, yang terutang oleh wajib pajak membayarnya menurut peraturan-peraturan umum (undang-undang) dengan tidak mendapat prestasi kembali yang langsung dapat ditunjuk secara langsung (Thomas Sumarsan, 2009:3).

b. Rochmat Sumitro, pajak adalah iuran rakyat kepada kas negara (peralihan kekayaan dari kas 
Rini Irianti Sundary, Pengalihan Bea Perolehan Hak Atas Tanah Dan Bangunan (Bphtb) Dari...

rakyat ke sektor pemerintah berdasarkan undang-undang) dapat dipaksakan dengan tiada mendapat jasa timbal (tegen prestasi) yang langsung dapat ditunjukkan dan digunakan untuk membiayai pengeluaran umum (Rochmat

\section{Soemitro, 1993:11).}

c. Sommerfeld Ray M., Anderson Herschel M., dan Brock Horace R., pajak adalah suatu pengalihan sumber dari sektor swasta ke sektor pemerintah, bukan akibat pelanggaran hukum, namun wajib dilaksanakan, berdasarkan ketentuan yang ditetapkan lebih dahulu, tanpa mendapat imbalan yang langsung dan proporsional, agar pemerintah dapat melaksanakan tugas-tugasnya untuk menjalankan pemerintahan (Muqodim, 1999:1).

Dari definisi definisi tersebut dapat ditarik suatu kesimpulan tentang ciri-ciri yang melekat pada pengertian pajak, sebagai berikut:

a. Iuran rakyat kepada negara, yang berhak memungut pajak hanyalah negara/pemerintah, baik pemerintah pusat maupun pemerintah daerah; b. Berdasarkan Undang Undang, pajak dipungut berdasarkan atau dengan kekuatan Undang Undang serta aturan pelaksanaannya. Oleh karena itu pemungutan pajak bisa dipaksakan. Sekalipun demikian walaupun negara mempunyai hak untuk memungut pajak namun pelaksanaannya harus memperoleh persetujuan dari rakyatnya melalui Undang Undang;

c. Tanpa jasa timbal atau kontra prestasi secara individual dari negara yang secara langsung dapat ditunjuk, dalam arti bahwa jasa timbal atau kontra prestasi yang diberikan oleh negara kepada rakyatnya tidak dapat dihubungkan secara langsung dengan besarnya pajak;

d. Untuk membiayai pengeluaran pemerintah yang bersifat umum, pajak diperuntukkan bagi pengeluaran rutin pemerintah. Dan jika masih surplus digunakan untuk "public saving" dan public saving ini yang akan digunakan untuk membiayai "public invesment".

Dari ke-4 (empat) ciri tersebut diatas, ciri ke-2 (dua) merupakan ciri 
Rini Irianti Sundary, Pengalihan Bea Perolehan Hak Atas Tanah Dan Bangunan (Bphtb) Dari...

yang paling menonjol dalam suatu negara modern karena pengalihan sumber-sumber (resources) dari sektor swasta ke sektor pemerintah harus selalu berdasarkan peraturan atau undang-undang, yang mana peraturan atau undang-undang tersebut telah mendapat persetujuan dari rakyat melalui wakil-wakilnya. Hal ini telah memunculkan sebuah slogan di negara-negara maju bahwa dalam pemungutan pajak berlaku istilah "no taxation without representation" yang artinya tidak ada pajak tanpa persetujuan dari wakil rakyat. Indonesia sebagai negara hukum telah menempatkan landasan pemungutan pajak dalam Undang Undang Dasar nya, yaitu Pasal 23 ayat (2) UUD 1945 yang berbunyi bahwa "Segala pajak untuk keperluan negara harus berdasarkan undang-undang". Hal ini dipertegas dalam penjelasan dari Pasal 23 ayat (2) tersebut, yaitu "Betapa caranya rakyat sebagai bangsa akan hidup dan dari mana didapatnya belanja buat hidup harus ditetapkan oleh rakyat itu sendiri, dengan perantaraan Dewan Perwakilannya. Rakyat menentukan nasibnya sendiri, karena itu juga cara hidupnya".

\section{Menurut}

Undang-Undang Nomor 28 Tahun 2009 tentang Pajak Daerah dan Retribusi, Pajak Daerah adalah iuran wajib yang dilakukan oleh pribadi atau badan kepada daerah tanpa imbalan langsung yang seimbang, dapat dipaksakan berdasarkan peraturan perundangan yang berlaku digunakan untuk penyelenggaraan pemerintahan, dan pembangunan daerah.

Dengan demikian, pajak daerah merupakan pajak yang ditetapkan oleh pemerintah daerah dengan peraturan daerah (PERDA), yang wewenang pemungutannya dilaksanakan oleh pemerintah daerah dan hasilnya digunakan untuk membiayai pengeluaran pemerintah daerah dalam melaksanakan penyelenggaraan pemerintahan dan pembangunan didaerah. Karena pemerintah daerah di Indonesia terbagi menjadi dua, yaitu pemerintah Provinsi dan Pemerintah Kabupaten/ Kota, maka wewenang pemungutannya ditetapkan oleh pemerintah daerah masing-masing yang diatur dalam undang-undang. 
Rini Irianti Sundary, Pengalihan Bea Perolehan Hak Atas Tanah Dan Bangunan (Bphtb) Dari...

Disamping pemungutan berbagai macam pajak, pemerintah masih dapat kewenangan untuk malakukan berbagai pungutan lain, antara lain:

a. Retribusi, menurut UndangUndang Nomor 28 Tahun 2009 tentang Pajak Daerah dan Retribusi adalah pungutan daerah sebagai pembayaran atas jasa atau pemberian izin tertentu yang khusus disediakan dan/atau diberikan oleh Pemerintah Daerah untuk kepentingan orang pribadi atau badan kepada pemerintah daerah. Berbeda dengan pajak pusat seperti Pajak Penghasilan dan Pajak Pertambahan Nilai yang dikelola oleh Direktorat Jenderal Pajak, Retribusi yang dapat di sebut sebagai pajak Pajak Daerah dikelola oleh Dinas Pendapatan Daerah (DISPENDA).

Jenis Pos Retribusi daerah dapat dikelompokan menjadi tiga (Undang-Undang Nomor 28 Tahun 2009), yaitu:

1) Retribusi Jasa Umum
a) Retribusi
Pelayanan Kesehatan;

b) Retribusi Pelayanan Persampahan/Kebersiha;

c) Penggantian Biaya Cetak Kartu Tanda Penduduk dan Akta Catatan Sipil;

d) Retribusi Pelayanan Pemakaman dan Pengabuan Mayat;

e) Retribusi Pelayanan Parkir di Tepi Jalan Umum;

f) Retribusi Pelayanan Pasar;

g) Retribusi Pengujian Kendaraan Bermotor;

h) Retribusi Pemeriksaan Alat Pemadam Kebakaran;

i) Retribusi Penggantian Biaya Cetak Peta;

j) Retribusi Penyediaan dan/atau Penyedotan Kakus;

k) Retribusi Pengolahan Limbah Cair;

1) Retribusi Pelayanan Tera/Tera Ulang;

m)Retribusi Pelayanan Pendidikan;

n) Retribusi Pengendalian Menara Telekomunikasi.

2) Retribusi Jasa Usaha

a) Retribusi Pemakaian Kekayaan Daerah;

b) Retribusi Pasar Grosir dan/atau Pertokoan;

c) Retribusi Tempat Pelelangan;

d) Retribusi Terminal;

e) Retribusi Tempat Khusus Parkir;

f) Retribusi Tempat Penginapan/Pesanggraha/Vil la;

g) Retribusi Rumah Potong Hewan;

h) Retribusi Pelayanan Kepelabuhanan;

i)Retribusi Tempat Rekreasi dan Olahraga; 
Rini Irianti Sundary, Pengalihan Bea Perolehan Hak Atas Tanah Dan Bangunan (Bphtb) Dari...

j)Retribusi Penyebrangan di Air;

k) Retribusi Penjualan Produksi Usaha Daerah.

3) Retribusi Perizinan

a) Retribusi Izin Mendirikan Bangunan;

b) Retribusi Izin Tempat Penjualan Minuman Beralkohol;

c) Retribusi Izin Gangguan;

d) Retribusi Izin Trayek;

e) Retribusi Izin Usaha Perikanan.

b. Sumbangan atau iuran yaitu pungutan yang dilakukan sehubungan dengan sesuatu jasa atau fasilitas yang diberikan pemerintah secara langsung dan nyata kepada sekelompok atau golongan pembayarnya atau golongan tertentu. Misalnya: SWP3D (Sumbangan Wajib Pembangunan dan Pemeliharaan Prasarana Daerah).

c. Cukai yaitu pungutan yang dikenakan atas barang-barang tertentu. Misalnya: cukai terhadap tembakau, cukai gula, cukai bensin, cukai minuman keras.

d. Bea Meterai yaitu pajak yang dikenakan atas dokumen dengan menggunakan benda meterai ataupun cara lainnya (menggunakan mesin teraan atau pemeteraian kemudian).
Sesuai Undang-Undang Nomor 28 Tahun 2009 tentang Pajak Daerah dan Retribusi Daerah, berikut jenisjenis Pajak Daerah:

a. Pajak Provinsi terdiri dari:

1) Pajak Kendaraan Bermotor;

2) Bea Balik Nama Kendaraan Bermotor;

3) Pajak Bahan Bakar Kendaraan Bermotor;

4) Pajak Air Permukaan; dan

5) Pajak Rokok.

b. Jenis Pajak Kabupaten/Kota terdiri atas:

1) Pajak Hotel;

2) Pajak Restoran;

3) Pajak Hiburan;

4) Pajak Reklame;

5) Pajak Penerangan Jalan;

6) Pajak Mineral Bukan Logam dan Batuan;

7) Pajak Parkir;

8) Pajak Air Tanah;

9) Pajak Sarang Burung Walet;

10) Pajak Bumi dan Bangunan Perdesaan dan Perkotaan; dan

11) Bea Perolehan Hak atas Tanah dan Bangunan.

Dari pengertian pajak daerah tersebut diatas maka dapat dimaknai bahwa pajak daerah merupakan wewenang daerah yang diatur dalam undang-undang dan hasilnya digunakan untuk membiayai rumah tangga daerah itu sendiri.

\section{Subyek Dan Obyek Serta Bukan Obyek BPHTB}


Rini Irianti Sundary, Pengalihan Bea Perolehan Hak Atas Tanah Dan Bangunan (Bphtb) Dari...

Bea Perolehan Hak atas Tanah dan Bangunan (BPHTB) adalah pajak yang dikenakan atas perolehan hak atas tanah dan atau bangunan. Perolehan Hak atas Tanah dan atau Bangunan adalah perbuatan atau peristiwa hukum yang mengakibatkan diperolehnya hak atas tanah dan atau bangunan oleh orang pribadi atau badan.

Hak atas tanah meliputi hak atas tanah termasuk hak pengelolaan, beserta bangunan diatasnya sebagaimana dalam Undang-Undang Nomor 5 Tahun 1960 Tentang Peraturan Dasar Pokok-Pokok Agraria dan peraturan perundangundangan yang berlaku.

Subjek BPHTB adalah orang pribadi atau badan yang memperoleh hak atas tanah dan atau bangunan. Subjek BPHTB yang dikenakan kewajiban membayar BPHTB menurut perundang-undangan perpajakan yang menjadi Wajib Pajak.

Objek BPHTB adalah perolehan hak atas tanah dan atau bangunan. Perolehan hak atas tanah dan atau bangunan adalah perbuatan (disengaja) atau peristiwa hukum (otomatis/tidak disengaja) yang mengakibatkan diperolehnya hak atas tanah dan atau bangunan oleh orang pribadi atau badan. Contoh peristiwa hukum adalah warisan karena pemilik meninggal dunia.

Yang menjadi objek pajak BPHTB adalah perolehan hak atas tanah dan atau bangunan, perolehan hak atas tanah dan atau bangunan, meliputi:

a. Pemindahan hak karena:

1) Jual beli;

2) Tukar-menukar;

3) Hibah;

4) Hibah waris;

5) Waris;

6) Pemasukan dalam perseroan atau badan hukum lainnya;

7) Pemisahan hak yang mengakibatkan peralihan;

8) Penunjukan pembeli dalam lelang;

9) Pelaksanaan putusan hakim yang mempunyai kekuatan hukum tetap;

10) Penggabungan usaha;

11) Peleburan usaha;

12) Pemekaran usaha;

13) Hadiah;

b. Pemberian hak baru karena: 
Rini Irianti Sundary, Pengalihan Bea Perolehan Hak Atas Tanah Dan Bangunan (Bphtb) Dari...

1) Pelanjutan pelepasan hak;

2) Diluar pelepasan hak.

Hak atas tanah adalah hak milik, hak guna usaha, hak guna bangunan, hak pakai, hak milik atas satuan rumah susun atau hak pengelolaan.

Objek Pajak yang Tidak Dikenakan BPHTB adalah objek pajak yang diperoleh:

a. Perwakilan diplomatik, konsulat berdasarkan asas perlakuan timbale balik;

b. Negara untuk penyelenggaraan pemerintahan dan atau untuk pelaksanaanpembangunan guna kepentingan umum;

c. Badan atau perwakilan organisasi internasional yang ditetapkan oleh menteri dengan syarat tidak menjalankan usaha atau menjalankan kegiatan lain diluar fungsi dan tugas badan atau perwakilan organisasi;

d. Orang pribadi atau badan karena konversi hak dan perbuatan hukum lain dengan tidak adanya perubahan nama;

e. Orang pribadi atau badan karena wakaf; f. Orang pribadi atau badan yang digunakan untuk kepentingan ibadah.

Ada beberapa macam dasar pengenaan BPHTB, yaitu:

a. Pengenaan BPHTB karena waris dan Hibah Wasiat BPHTB yang terutang atas perolehan hak karena waris dan hibah wasiat adalah sebesar 50\% dari BPHTB yang seharusnya terutang.

b. Pengenaan BPHTB karena pemberian Hak Pengelolaan. Besarnya BPHTB karena pemberian Hak Pengelolaan adalah sebagai berikut:

1) $0 \%$ (nol persen) dan BPHTB yang seharusnya terutang terutang dalam hal penerima Hak Pengelolaan adalah Departemen, Lembaga Pemerintah Non Departemen, Pemerintah Daerah Propinsi, Pemerintah Daerah Kabupaten/kota, Lembaga Pemerintah lainnya, dan Perusahaan Umum Pembangunan Perumahan Nasional (Perum Perumnas);

2) $50 \%$ (lima puluh persen) dari BPHTB yang seharusnya 
Rini Irianti Sundary, Pengalihan Bea Perolehan Hak Atas Tanah Dan Bangunan (Bphtb) Dari...

terutang dalam hal penerima

Hak Pengelolaan selain dimaksud diatas.

\section{Pengalihan BPHTB Dari}

Pajak Pusat Menjadi Pajak Daerah

Secara konsepsional, terdapat beberapa dasar pemikiran mengenai kebijakan pengalihan BPHTB yang semula sebagai pajak pusat menjadi pajak daerah, antara lain:

a. BPHTB layak ditetapkan sebagai pajak daerah

BPHTB memenuhi kriteria dan prinsip-prinsip pajak daerah yang baik, seperti:

1) Objek pajaknya terdapat di daerah (local-origin);

2) Objek pajak tidak berpindahpindah (im-movable), dan

3) Terdapat hubungan yang erat antara pembayar pajak dan pihak yang menikmati hasil pajak tersebut (the benefit-tax link principle).

\section{b. Meningkatkan Pendapatan Asli} Daerah

Penetapan BPHTB sebagai pajak daerah akan meningkatkan pendapatan yang bersumber dari daerah itu sendiri (Pendapatan Asli
Daerah). Hal ini berbeda dengan penerimaan BPHTB sebagai pajak pusat, meskipun pendapatan BPHTB kemudian diserahkan kepada daerah, penerimaan ini tidak dimasukkan ke dalam kelompok pendapatan asli daerah, melainkan sebagai dana perimbangan (Dana Bagi Hasil).

c. Meningkatkan akuntabilitas daerah (local accountability)

Dengan menetapkan BPHTB sebagai pajak daerah, maka kebijakan BPHTB ditetapkan oleh daerah dan diseuaikan dengan kondisi, dan tujuan pembangunan daerah.

Dalam melaksanakan pungutan BPHTB, pemerintah daerah harus membuat Peraturan Daearah, Sebelumnya sebagai Peraturan Pelaksana dari UndangUndang Nomor 28 Tahun 2009 yang berkaitan dengan BPHTB, telah dibentuk Sekurangkurangnya terdapat 6 (enam) peraturan pelaksanaan UndangUndang Nomor 28 Tahun 2009 yang berkaitan dengan BPHTB, yaitu: 
Rini Irianti Sundary, Pengalihan Bea Perolehan Hak Atas Tanah Dan Bangunan (Bphtb) Dari...

1) Peraturan Bersama Menteri Keuangan dan Menteri Dalam Negeri Nomor 186/PMK.07/2010 dan Nomor 53 Tahun 2010 tentang Tahapan Persiapan Pengalihan BPHTB sebagai pajak daerah. Peraturan ini mengatur tugas dan tanggung jawab kementrian Keuangan, Kementerian dalam negeri dan pemerintah daerah terkait dengan proses pengalihan BPHTB menjadi pajak daerah.

2) Peraturan Menteri Keuangan Nomor 147/PMK.07/2010 tentang Badan atau Perwakilan Lembaga Internasional yang tidak dikenakan BPHTB. Dalam peraturan ini ditetapkan sejumlah badan dan perwakilan lembaga internasional yang tidak dikenakan BPHTB, seperti badan-badan internasional dari PBB, kerjasama bilateral, Colombo Plan, kerjasama kebudayaan, organisasi swasta internasional, dan organisasi asing lainnya.

3) Peraturan Pemerintah Nomor 69 Tahun 2010 tentang tatacara pemberian dan pemanfaatan Insentif Pemungutan Pajak Daerah dan Retribusi Daerah. Peraturan ini mengatur pihakpihak yang dapat menerima insentif pemungutan pajak daerah, termasuk pemungutan BPHTB, beserta persyaratan dan besarannya.

4) Peraturan Pemerintah Nomor 91 Tahun 2010 tentang jenis pajak daerah yang dipungut berdasarkan penetapan kepala daerah atau dibayar sendiri oleh wajib pajak. Dalam peraturan ini ditetapkan bahwa pemungutan BPHTB dilakukan berdasarkan prinsip selfassessment, yakni wajib pajak membayar sendiri pajak yang terutang.

5) Peraturan Menteri Dalam Negeri Nomor 56 Tahun 2010 tentang perubahan atas Peraturan Menteri Dalam Negeri Nomor 57 Tahun 2007 tentang petunjuk teknis penataan organisasi perangkat daerah.

6) Peraturan Menteri Keuangan Nomor 11/PMK.07/2010 
Rini Irianti Sundary, Pengalihan Bea Perolehan Hak Atas Tanah Dan Bangunan (Bphtb) Dari...

tentang tatacara pengenaan

sanksi terhadap pelanggaran ketentuan di bidang pajak daerah dan retribusi daerah. Dalam peraturan ini ditetapkan sanksi bagi daerah yang melakukan pelanggaran ketentuan di bidang pajak daerah, termasuk BPHTB, dalam 2 (dua) bentuk, yaitu:

a) Atas pelanggaran administrasi dikenakan sanksi berupa penundaan DAU atau DBH Pajak Penghasilan;

b) Atas pelanggaraan substansi dikenakan sanksi berupa pemotongan DAU atau DBH Pajak Penghasilan.

7) Perumusan peraturan pelaksanaan tersebut dilakukan secara paralel dengan berbagai kegiatan dalam rangka implementasi UU pajak daerah dan retribusi daerah yang baru. Penyusunan peraturan tersebut dapat diselesaikan dalam tahun 2010 , sebagaimana diamanatkan dalam Nomor 28 Tahun 2009.
8) Peraturan Bersama Menteri Keuangan Dan Menteri Dalam Negeri Nomor 186/PMK.07/2010 Nomor 53 Tahun 2010 tanggal 18 Oktober 2010, tentang Tahapan Persiapan Pengalihan Bea Perolehan Hak Atas Tanah dan Atau Bangunan sebagai Pajak Daerah.

9) Peraturan Direktur Jenderal Pajak Nomor PER-47/PJ/2010 tanggal 22 Oktober 2010, tentang Tata Cara Persiapan Pengalihan Bea perolehan Hak Atas Tanah dan bangunan sebagai Pajak Daerah.

\section{d. Prinsip-Prinsip Umum} Perpajakan Daerah

Prinsip-prinsip umum perpajakan daerah pada dasarnya sama dengan sistem perpajakan yang dianut oleh kebanyakan negara di dunia, yaitu harus memenuhi kriteria umum tentang perpajakan (Santoso R. Brotidihardjo, 2003:2), sebagai berikut:

1) Prinsip memberikan pendapatan yang cukup dan elastis, artinya dapat mudah naik turun 
Rini Irianti Sundary, Pengalihan Bea Perolehan Hak Atas Tanah Dan Bangunan (Bphtb) Dari...

mengikuti naik/turunnya pendapatan masyarakat;

2) Adil dan merata secara vertikal artinya sesuai dengan tingkat kelompok masyarakat sehingga tidak ada yang kebal pajak;

3) Administrasi yang fleksibel artinya sederhana, mudah dihitung, pelayanan memuaskan bagi wajib pajak;

4) Secara politis dapat ditermia oleh masyarakat, sehingga timbul motivasi dan kesadaran pribadi untuk membayar pajak. Non-distorsi terhadap perekonomian: implikasi pajak atau pungutan yang hanya menimbulkan pengaruh minimal terhadap perekonomian. Pada dasarnya setiap pajak atau pungutan akan menimbulkan suatu beban baik bagi konsumen maupun produsen. Jangan sampaisuatu pajak atau pungutan menimbulkan beban tambahan (extra burden) yang berlebihan, sehingga akan merugikan masyarakat serta menyeluruh (dead-weight loss).
Dari uraian di atas, untuk sementara maka dapat disimpulkan bahwa BPHTB sebagai salah satu bentuk pajak daerah dalam pelaksanaannya harus memenuhi kriteria-kriteria di atas, aspek filosofis, yuridis dan sosiologis. Ketiga aspek itu merupakan prasyarat utama yang menentukan apakah suatu aturan itu dapat mengikat dan diterima dengan baik oleh masyarakat.

\section{SIMPULAN}

1. BPHTB layak ditetapkan sebagai pajak daerah, karena BPHTB memenuhi kriteria dan prinsip-prinsip pajak daerah yang baik, sepert: objek pajaknya terdapat di daerah (local-origin), objek pajak tidak berpindah-pindah (im-movable), dan terdapat hubungan yang erat antara pembayar pajak dan pihak yang menikmati hasil pajak tersebut (the benefit-tax link principle).

2. Penetapan BPHTB sebagai pajak daerah akan meningkatkan pendapatan yang bersumber dari daerah itu 
Rini Irianti Sundary, Pengalihan Bea Perolehan Hak Atas Tanah Dan Bangunan (Bphtb) Dari...

sendiri (Pendapatan Asli

Daerah) Hal ini berbeda dengan penerimaan BPHTB sebagai pajak pusat, meskipun pendapatan BPHTB kemudian diserahkan kepada daerah, penerimaan ini tidak dimasukkan ke dalam kelompok pendapatan asli daerah, melainkan sebagai dana perimbangan (Dana Bagi Hasil). BHPTB sebagai pajak daerah juga dapat meningkatkan akuntabilitas daerah (local accountability). Dengan menetapkan BPHTB sebagai pajak daerah, maka kebijakan BPHTB ditetapkan oleh daerah dan diseuaikan dengan kondisi, dan tujuan pembangunan daerah.

\section{D.SARAN}

1. Pemerintah daerah dalam hal ini daerah Kabupaten/Kota, agar segera menyiapkan diri dan strategi melalui pola pendekatan kemasyarakatan, agar peraturan Bupati yang akan dibentuk benar-benar diterima dan masyarakat mentaatinya dengan penuh kesadaran,

2. Agar segera disusun tatacara pemungutan BPHTB (Standar Operating Proocedures) dengan menerbitkan Peraturan Bupati/Peraturan Walikota yang memenuhi landasar pembentukan peraturan Perundang-undangan yang baik.

\section{DAFTAR PUSTAKA}

Muqodim, Perpajakan Buku Satu, Edisi Revisi, UII Press dan Ekonesia. Yogyakarta, 1999.

Rochmat Soemitro, Dasar-Dasar Perpajakan, Eresco, Bandung, 1999.

Ronny Hanitio Soemitro, Metodologi Penelitian Hukum, Ghalia Indonesia, Jakarta, 1982.

Santoso R Brotodihardjo, Pengantar Ilmu Hukum Pajak, Jakarta, 2003.

Sudikno Mertokusumo dan A. Pitlo, Bab-bab tentang Penemuan Hukum, PT. Citra Aditya Bhakti, Bandung, 1993.

Thomas Sumarsan, Perpajakan Indonesia, Esia Media, Jakarta, 2009.

Undang-Undang Dasar 1945. 
Rini Irianti Sundary, Pengalihan Bea Perolehan Hak Atas Tanah Dan Bangunan (Bphtb) Dari...

Undang-Undang Nomor 28 Tahun 2009 Tentang Pajak Daerah dan Retribusi Daerah.

Undang-Undang Nomor 12 Tahun 2011 Tentang Pembentukan Peraturan Perundangundangan.

Undang-Undang Nomor 23 Tahun 2014 Tentang Pemerintahan Daerah.

Peraturan Bersama Menteri Keuangan dan Menteri Dalam Negeri Nomor 186/PMK.07/2010 dan Nomor 53 Tahun 2010 tentang Tahapan Persiapan Pengalihan BPHTB sebagai pajak daerah.

Peraturan Menteri Keuangan Nomor 147/PMK.07/2010 tentang Badan atau Perwakilan
Lembaga Internasional yang tidak dikenakan BPHTB.

Kementrian Keuangan, Direktorat Jenderal Perimbangan Keuangan, 2011. 